\title{
Physicochemical Characterization of Agricultural Run-off and Groundwater Inoculated by Trichoderma asperellum and its Effect on Anti-oxidative Enzymes Production by Irrigated Trifolium alexandrinum L.
}

\author{
Tarek M. Abdel Ghany, ${ }^{\mathrm{a}, *}$ Mohamed S. Mahmoud, ${ }^{\mathrm{b}}$ Mohamed M. Alawlaqi, ${ }^{\mathrm{c}}$ \\ Ahmed M. Reyad, ${ }^{\mathrm{c}, \mathrm{d}}$ Aisha M.H. Al-Rajhi, ${ }^{\mathrm{e}}$ and Eman M. Abdkareem ${ }^{\mathrm{f}}$
}

\begin{abstract}
Water safety and security has become a great problem in recent years, as the shortage of water resources in most countries is becoming an increasingly serious issue. Therefore, searching for new water sources or treating contaminated water has become a major requirement to covering the shortage of fresh water. The current study evaluated the impact of Trichoderma asperellum on the physicochemical characterization of agricultural run-off (AR) compared with groundwater (GW). Chemical oxygen demand (COD), biological oxygen demand $\left(B D_{5}\right)$, ammonia, total nitrogen (TN), and total dissolved salts (TDS) of AR were higher than that of GW with $90,90.2,91.9,78$, and $61.6 \%$, respectively. The addition of $T$. asperellum to AR caused the COD, $\mathrm{BOD}_{5}$, ammonia, TN, and TDS to decrease $47.2,39.2,16.2,12.9$, and $4.8 \%$, respectively. Contents of metals in AR or GW were decreased by $T$. asperellum. Microbial analysis of soil irrigated by AR in contrast to irrigated by GW showed the presence of a high number of bacteria $\left(32 \times 10^{6} \mathrm{CFU}\right)$, actinomycetes $\left(18 \times 10^{4}\right.$ $\mathrm{CFU})$, and fungi $\left(13 \times 10^{4} \mathrm{CFU}\right)$. Trifolium alexandrinum growth and its antioxidant enzymes activities (catalase, superoxide dismutase, and ascorbate peroxidase) were enhanced by AR inoculated by $T$. asperellum compared with un-inoculated AR or GW.
\end{abstract}

Keywords: Trichoderma asperellum; Agricultural run-off; Oxidative enzymes; Plant growth

Contact information: a: Botany and Microbiology Department, Faculty of Science, Al-Azhar University, Cairo, Egypt 11725; b: Sanitary and Environmental Engineering Institute (SEI), Housing and Building National Research Center (HBRC), Egypt; c: Biology Department, Faculty of Science, Jazan University, Jazan, Saudi Arabia; d: Botany and Microbiology Department, Faculty of Science, Beni-Suef University, Beni-Suef, Egypt; e: Biology Department, Faculty of Science, Princess Nourah Bent Abdularahman University, Riyadh, Saudi Arabia; f: Biotechnology Central Lab, Plant Pathology Research Institute, Agricultural Research Center, Egypt; *Corresponding author: tabdelghany.201@azhar.edu.eg

\section{INTRODUCTION}

In recent decades, treatment of polluted water either sewage, industrial, or agricultural has attracted attention of researchers and governorates of all countries to compensate for the perceived shortage of fresh water not only for human uses but for apicultural and industrial application utilization.

The surface run-off from farmland outflow, namely agricultural runoff (AR), contains high amounts of pollutants such as phosphorus compounds, nitrates, ammonium, heavy metals, besides persistent organic pollutants (Wang et al. 2018). AR and sewage water (SW) have become available in large quantities due to the increase in population and the rational and intensive use of fresh water. Therefore, these are being considered as 
alternative sources for irrigation of plants. However, according to numerous literature on the analysis of plant nutrients, AR and other wastewater may contain poisonous organic compounds with highly dangerous impacts on human and animal health. Moreover, municipal wastewater contains high numbers of microorganisms if has not been disinfected or treated by appropriate methods. To avoid the potential toxicity and serious risks of municipal wastewater, crop contamination with pathogens, and intestinal helminths, municipal wastewater must be used for irrigation (Aiello et al. 2007; Zavadil 2009). Earlier studies have compared freshwater (FW) or groundwater $(\mathrm{GW})$ with reclaimed water $(\mathrm{RW})$. Higher salts, minerals, such as N, P, and K, and organic nutrients, organic pollutants, heavy metals, and dissolved organic matter (DOM), beside the presence of high content of microbes were detected in RW.

Surprisingly, some studies mentioned the environmental and economic benefits of RW, while others mentioned many defects. For example, of the economic benefits, Singh et al. (2012) reported that irrigation with RW minimizes the use of FW or GW, reuses nutrients in RW, and enhances crop productivity. Other scholars' studies (Lado and BenHur 2010; Xue et al. 2012) highlight some problems resulting from irrigation by RW. These includes increased salinity of soil, soil greenhouse gas emission, heavy metals, and xenobiotic organic molecules in crops, minimized soil saturated hydraulic conductivity, and contaminated GW. Other studies (Reyes-Solis et al. 2003; Bedbabis et al. 2010) have shown that salinity, greenhouse gas emission, microbes, and heavy metals were not affected by RW irrigation.

When facing the shortage of clear water resources, municipal wastewater is an essential alternative source to be used for plant irrigation to make up for the shortage of water. Although some contents of municipal wastewater contribute for plant nutrients, the water may contain various potentially toxic elements and organic matters with highly harmful effects on human and animal health. If wastewater is not treated or disinfected, this may promote the growth of microbes, especially pathogens. Therefore, the utilization of un-treated or un-disinfected municipal wastewater for the irrigation of crops is associated with a number of risks. In the current decade, RW has been applied for plant irrigation in many countries but at a secondary treatment stage that was characterized by decreasing contents of salts, xenobiotic organic materials, and heavy metals (Gomez et al. 2013). Other benefits of RW application were observed as a result decomposition of organic compounds in municipal wastewater in the agricultural soils; this can increase the population of saprophytic microorganisms as well as fungi such as Penicillium spp., Tricoderma spp., and Aspergillus spp. (Manici et al. 2004). Some of these fungi can act as antagonists of soil-borne phyto-pathogens and act as bio-fertilizers as an alternative to chemical fertilizers.

Numerous fungi associated to Trichoderma, Penicillium, Aspergillus, Spicaria, Acremonium, Trichothecium, Chrysosporium, and Hyaloflorae have been isolated from different sources of polluted water such as wastewater and sewage sludge (Fakhrul-Razi et al. 2002). From earlier literature, these fungi and others were applied for treatment of wastewater. According to Behnami et al. (2018), fungi were as efficient as bacteria in the elimination of organic pollutants from wastewater. From twenty-two fungi, seven fungi were found to have potential for nitrogen, ammonium and phosphorus treatment of municipal wastewater (Guest and Smith 2007).

Removing of heavy metals from contaminated water was performed recently using T. brevicompactum (Zhang et al. 2020) and previously by other fungi (Abdel-Razek et al. 2009a,b). The presence of multiple functional groups such as amide, hydroxyl, and 
carbonyl in fungi play a critical role during bioremediation of heavy metals from water sources (Manna et al. 2020). In this sense, the application of AR in irrigation of plants without any treatment is often associated with some health risk. The current study was performed to compare the impact of Trichoderma asperellum on physicochemical characteristics of AR and $\mathrm{GW}$, in addition to its impact on oxidative enzyme production by Trifolium alexandrinum.

\section{EXPERIMENTAL}

\section{Materials}

$A R$ and $G W$ Collections

Samples of AR were collected in sterile bottles from an agricultural drainage channel (30 62'8014" N, 116 31' 070334" E) (Fig. 1) in Ashmun, Monufia Governorate, Egypt. Over the past 10 years, these channels also have become a place to collect municipal water. The GW was collected from a pump drawing from a depth of $18 \mathrm{~m}$ at the same position of AR collection.

\section{Cultures used}

Trichoderma asperellum was provided by professor Tarek M. Abdel-Ghany (Abdel-Ghany et al. 2018). The species was identified based on DNA's ITS regions, and it was used for co-inoculant in AR and GW for 10 days, followed by physicochemical characterization analysis.

\section{Analytical techniques for physicochemical characterization of $A R$ and $G W$}

All physicochemical analysis, such as $\mathrm{pH}$, dissolved oxygen (DO), chemical oxygen demand (COD), biological oxygen demand (BOD5), total phosphorous (TP), ammonia nitrogen ( $\mathrm{NH} 4)$, nitrate $\left(\mathrm{NO}_{3}\right)$, total nitrogen (TN), total suspended solids (TSS), and total dissolved salts (TDS) in AR and GW were carried out in accordance with the American Public Health Association (APHA) (Rice et al. 2017; Su et al. 2019, 2020). Gas chromatography (GC), (Dani, Rome, Italy) using flame ionized detector (FID), column length (L): $60 \mathrm{~m}$, with limit of detection of $1 \mathrm{ug} . \mathrm{L}^{-1}$ was used for analyses of hydrocarbon pollutant determination. An ICE 3000 Series AA spectrometer (Thermo Fisher Scientific China Co., Ltd., Shanghai, China) atomic absorption spectrophotometer (AAS) was used for metal detection. A pH meter (pH-700, EUTECH, Singapore) was used for measuring $\mathrm{pH}$ value, with a range of 0.00 to 14.00 and an accuracy of \pm 0.02 . Millipore (Elix) UVMilli-Q Advantage A 10 System (Molsheim, France) with double-distilled water (DDW) from Millipore Instrument was used throughout the study for standard preparation.

\section{Seed germination and growth parameters}

Twenty five seeds of Trifolium alexandrinum (provided from Pure Seeds Company for Trade \& Export of Cereals \& Agricultural Crops, Egypt) were sterilized by mercuric chloride $(0.1 \% \mathrm{w} / \mathrm{v})$ up to $4 \mathrm{~min}$, followed by washing in sterile distilled water. Germination of seeds was carried on sterile filter paper in plastic dishes $(9 \mathrm{~cm})$, the seeds were irrigated by $\mathrm{AR}$ and $\mathrm{GW}$ inoculated by T. asperellum. At 15 days, seed germination $\%$, length, fresh weight, and antioxidant enzymes were recorded. Pure Seeds Co. for Trade \& Export of Cereals \& Agricultural Crops, Egypt. 
Antioxidant enzymes of T. alexandrinum

The enzymes activities were measured in $0.2 \mathrm{~g}$ of shoot system (leaves and stems) of T. alexandrinum that was ground in $10 \mathrm{~mL}$ of $50 \mathrm{mM}$ phosphate buffer $\mathrm{pH}$ (7.8) followed by centrifugation at $13000 \times \mathrm{g}$ for $15 \mathrm{~min}$. The obtained supernatant was used for the assay of enzymes activity.

Catalase (CAT), ascorbate peroxidase (APX), and superoxide dismutase (SOD)

According to Havir and McHale (1987), the activity of CAT was assayed using phosphate buffer $\left(100 \mathrm{mmol} . \mathrm{L}^{-1}, 7.0 \mathrm{pH}\right), \mathrm{H}_{2} \mathrm{O}_{2}\left(12.5 \mathrm{mmol} . \mathrm{L}^{-1}\right)$ and $0.1 \mathrm{~mL}$ of enzyme extract as a reaction solution $(3 \mathrm{~mL})$. At $240 \mathrm{~nm}$ absorbance, a reduction in activity of CAT was estimated, which was due to $\mathrm{H}_{2} \mathrm{O}_{2}$ consumption. The CAT activity (one unit) is defined as a change in absorbance of $0.01 \mathrm{unit} / \mathrm{min}$. According to Nakano and Asada (1981), the activity of APX was assayed using phosphate buffer (100 mmol.L $\left.\mathrm{L}^{-1}, \mathrm{pH} 7\right), 0.5 \mathrm{mmol} . \mathrm{L}^{-1}$ ascorbic acid, $\mathrm{H}_{2} \mathrm{O}_{2}\left(0.1 \mathrm{mmol} . \mathrm{L}^{-1}\right)$, and $0.1 \mathrm{~mL}$ enzyme extract as a reaction solution (3 $\mathrm{mL}$ ) depending on the oxidation of ascorbate. At $290 \mathrm{~nm}$ the absorbance was estimated for recording APX activity that was due to the peroxidation of $\mathrm{H}_{2} \mathrm{O}_{2}$ and guaiacol as an electron donor. The activity was expressed as unit/min. According to Giannopolitis and Ries (1977), the activity of SOD was assayed through measuring the inhibition rate of nitrobluetetrazolium (NBT) photo-reduction. Where the supernatant of the enzyme was added to the reaction mixture containing of potassium phosphate $\left(50\right.$ mmol. $\left.\mathrm{L}^{-1}, \mathrm{pH} 7.8\right), 75 \mu \mathrm{mol} \mathrm{L} \mathrm{L}^{-1}$ NBT, $14 \mathrm{mmol} \mathrm{L}{ }^{-1}$, methionine, $0.1 \mu \mathrm{mol} . \mathrm{L}^{-1}$ ethylene di-amine tetraacetic acid (EDTA), and $2 \mu \mathrm{mol} . \mathrm{L}^{-1}$ riboflavin. Then, reaction mixture was exposed to $20-\mathrm{W}$ fluorescent lamp for $6 \mathrm{~min}$, followed by measuring the absorbance at $560 \mathrm{~nm}$ using a UV-visible spectrophotometer. The SOD activity (one unit) was defined by $50 \%$ photochemical inhibition reduction of NBT.

\section{Microflora of soil irrigated by $A R$ and $G W$}

A plate-counting method was applied for determining fungi, bacteria, and actinomycetes represented by the number of colony forming units (CFU). One gram was taken from $20 \mathrm{~cm}$ depth of each fresh soil irrigated by AR and GW was suspended in $9 \mathrm{~mL}$ of saline solution $(0.9 \% \mathrm{NaCl})$. Series dilution of soil suspension ranged from $10^{-1}$ to $10^{7}$ and was prepared under sterile conditions to avoid the microbial contamination from air or from any other sources. Bacteria, actinomycetes, and fungi were cultivated on nutrient, starch nitrate, Czapek-Dox agar media, and incubated at 2, 3, and 5 days, respectively, at $37{ }^{\circ} \mathrm{C}$ for bacteria and actinomycetes, at $25^{\circ} \mathrm{C}$ for fungi. Then, the average $\mathrm{CFU}$ was recorded.

\section{RESULTS and DISCUSSION}

\section{Physicochemical Characterization of AR and GW}

Scarcity of fresh water in numerous countries has increased rapidly in the last decade with increased population and has become one of the main challenges for humanity. Therefore, evaluation and management of sewage water for its re-consumption is an attractive option currently. Water scarcity is one of the main problems for farmers, which tempts them to use wastewater for crop irrigation (Al-Tabbal et al. 2016). 
Results of the physicochemical parameters of treated and untreated GW and AR by T. asperellum are depicted (Table 1). The results of the analysis revealed that T. asperellum reduced all detected chemical parameters. There were big differences among chemical contents of GW and AR. The concentration of COD, BOD5, TP, NH4, TN, and DO was $18,10,0.12,0.3,1.9$, and $4.15 \mathrm{mg} . \mathrm{L}^{-1}$ in $\mathrm{GW}$ (control) while in AR (control) it was 180 , $102,0.72,3.7,8.64$, and $2.22 \mathrm{mg} . \mathrm{L}^{-1}$, respectively. The higher values of the physicochemical parameters observed in AR indicate higher pollution level.

By treating with $T$. asperellum, a negligible reduction in the GW contents was observed, while an effective reduction was observed in the contents of AR. For example, COD and BOD5 were reduced from 180 to 95 and from 102 to 62 when reduction reached to $47.22 \%$ and $39.22 \%$, respectively. Applications of T. asperellum within agriculture was elucidated in many studies as biocontrol agent or as biofertilizer. As previously mentioned by Hultberg and Bodin (2019), treatment by T. asperellum achieved a significantly greater COD reduction during real brewery waste streams treatment. Zhang et al. (2008) reported a more positive result using the related species $T$. viride to treat winery wastewater, where COD reductions in the range of 86 to $91 \%$ after $24 \mathrm{~h}$ at a cultivation temperature of $30{ }^{\circ} \mathrm{C}$ were achieved. In recent study, Narendran et al. (2019) concluded that a Trichoderma strain was most effective in the of wastewater treatment, due to its high capability for reducing not only $\mathrm{COD}$, but also other nutrients.

The TP was reduced in GW and AR after T. asperellum application (Table 1). These fungi demonstrated an ability to accumulate $\mathrm{P}$ in poly-P granules. Ye et al. (2015) investigated the potential of Mucor circinelloides for phosphorus (P) removal from wastewater, the largest consumption efficiency was $40.1 \%$ for $\mathrm{P}$ and $7.08 \%$ for cellular $\mathrm{P}$ content.

Reduction of TSS in GW and AR was observed as a result of T. asperellum from $13 \mathrm{mg} . \mathrm{L}^{-1}$ before treatment to $10 \mathrm{mg} . \mathrm{L}^{-1}$ and $115 \mathrm{mg} . \mathrm{L}^{-1}$ before treatment to $75 \mathrm{mg} . \mathrm{L}^{-1}$, respectively. The $\mathrm{pH}$ of the $\mathrm{GW}$ was 7.79 , indicating that it was more alkaline than $\mathrm{AR}$ ( $\mathrm{pH} 7.33$ ) but $T$. asperellum lowered alkalinity feature of $\mathrm{GW}(\mathrm{pH} 7.61)$ unlike sewage water ( $\mathrm{pH}$ became 7.36) (Table 1). A pH 6.5 to 8 is considered standard for irrigation according to the food and agriculture organization (FAO). From the previous study, $T$. harzianum showed efficient degrading capabilities by degrading the contaminants as they use it for their growth and reproduction (Kashif and Monowar 2017).

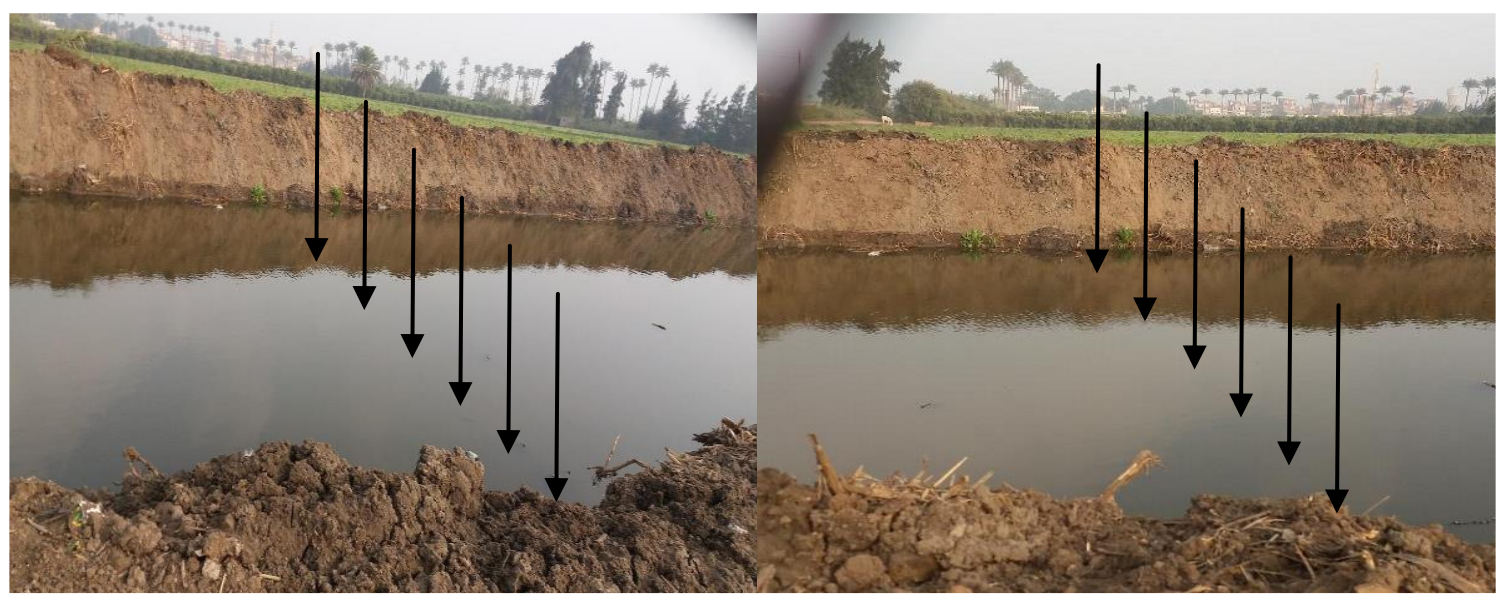

Fig. 1. AR collection site. Arrows are pointing to the samples were collected in a row from a line that crossed the channel at distance $2 \mathrm{~m}$. 
Table 1. Physicochemical Parameters of GW and AR Inoculated by $T$. asperellum

\begin{tabular}{|c|c|c|c|c|}
\hline \multirow{2}{*}{$\begin{array}{l}\text { Physicochemical } \\
\text { Parameters }\end{array}$} & \multicolumn{4}{|c|}{ Type of Water } \\
\hline & $\begin{array}{c}\text { GW } \\
\text { (Control) }\end{array}$ & $\begin{array}{c}\text { GW } \\
\text { (Inoculated) }\end{array}$ & $\begin{array}{c}\text { AR } \\
\text { (Control) }\end{array}$ & $\begin{array}{c}\text { AR } \\
\text { (Inoculated) }\end{array}$ \\
\hline $\mathrm{COD}\left(\mathrm{mg} \cdot \mathrm{L}^{-1}\right)$ & 18 & 16 & 180 & 95 \\
\hline $\mathrm{BOD}_{5}\left(\mathrm{mg} \mathrm{L}^{-1}\right)$ & 10 & 8 & 102 & 62 \\
\hline $\mathrm{TP}\left(\mathrm{mg} \cdot \mathrm{L}^{-1}\right)$ & 0.12 & 0.09 & 0.72 & 0.53 \\
\hline $\mathrm{NH}_{4}\left(\mathrm{mg} \cdot \mathrm{L}^{-1}\right)$ & 0.3 & 0.1 & 3.7 & 3.1 \\
\hline $\mathrm{NO}_{3}\left(\mathrm{mg} \mathrm{L}^{-1}\right)$ & 0.0 & 0.0 & 0.0 & 0.0 \\
\hline $\mathrm{TN}\left(\mathrm{mg} \cdot \mathrm{L}^{-1}\right)$ & 1.9 & 1.3 & 8.64 & 7.52 \\
\hline Oils and Greases $\left(\mathrm{mg} \mathrm{L}^{-1}\right)$ & 0.003 & 0.004 & 0.008 & 0.006 \\
\hline $\mathrm{DO}\left(\mathrm{mg} \cdot \mathrm{L}^{-1}\right)$ & 4.15 & 4.2 & 2.22 & 2.20 \\
\hline TSS $\left(m g . L^{-1}\right)$ & 13 & 10 & 115 & 75 \\
\hline TDS $\left(\mathrm{mg} \mathrm{L}^{-1}\right)$ & 480 & 477 & 1250 & 1190 \\
\hline $\mathrm{pH}$ & 7.79 & 7.61 & 7.33 & 7.36 \\
\hline
\end{tabular}

The current findings indicated that $T$. asperellum was effective in removing or decreasing some detected metal (Table 2). For example, lead was reduced to $57.14 \%$ and $37.50 \%$ in GW and AR, respectively. Copper completely disappeared as a result of $T$. asperellum treatment in AR. The efficacy of $T$. asperellum on copper and lead predict its efficacy on other non-detected serious metal in either GW or AR, such as chromium, arsenic, and mercury, if present in any contaminated water resources. At application level in the current finding, T. asperellum provides good advantages; for example, it is nonpathogenic and a non-toxins producer compared to prior studied mycotoxigenic fungi. A similar result was reported earlier (Mohsenzadeh and Shahrokhi 2014; Hoseinzadeh et al. 2017), where T. asperellum was used for removing metal from wastewater and heavy metal contaminated soils. Heavy metals eliminating from AR or GW inoculated by T. asperellum may be due to the presence of the efficacy groups such as carboxylic, hydroxyl, amine, and amide in fungal cells. These explanations were given in a recent study (Manna et al. 2020).

Table 2. Metal Analysis of GW and AR Inoculated by T. asperellum

\begin{tabular}{|c|c|c|c|c|}
\hline \multirow{2}{*}{ Metal } & \multicolumn{4}{|c|}{ Metal Concentration $\left(\mathrm{mg} \cdot \mathrm{L}^{-1}\right.$ ) of Water } \\
\cline { 2 - 5 } & GW (Control) & $\begin{array}{c}\text { GW } \\
\text { (Inoculated) }\end{array}$ & $\begin{array}{c}\text { AR } \\
\text { (Control) }\end{array}$ & $\begin{array}{c}\text { AR } \\
\text { (Inoculated) }\end{array}$ \\
\hline Chromium & 0.0 & 0.0 & 0.0 & 0.0 \\
\hline Copper & 0.0 & 0.0 & 0.002 & 0.0 \\
\hline Lead & 0.007 & 0.003 & 0.008 & 0.005 \\
\hline Cadmium & 0.0 & 0.0 & 0.0 & 0.0 \\
\hline Zinc & 0.0022 & 0.0015 & 0.019 & 0.013 \\
\hline Arsenic & 0.0 & 0.0 & 0.0 & 0.0 \\
\hline Selenium & 0.0 & 0.0 & 0.0 & 0.0 \\
\hline Mercury & 0.0 & 0.0 & 0.0 & 0.0 \\
\hline Manganese & 0.053 & 0.005 & 0.003 & 0.001 \\
\hline Iron & 0.065 & 0.062 & 0.029 & 0.022 \\
\hline
\end{tabular}

Analysis of organics of un-inoculated AR (C) and inoculated AR (T) by $T$. asperellum using $\mathrm{GC}$ indicated significant removal for the majority of tested compounds after treatment process, as shown in Table 3 and Figs. 2a and $2 \mathrm{~b}$. 
Table 3. GC Analysis of Hydrocarbons (mg. $\left.\mathrm{L}^{-1}\right)$ in Inoculated and Un-inoculated AR with $T$. asperellum

\begin{tabular}{|c|c|c|c|c|c|c|c|}
\hline \multirow[b]{2}{*}{ Compound Name } & \multirow[b]{2}{*}{ MF } & \multirow[b]{2}{*}{ MW } & \multicolumn{2}{|c|}{ Inoculated } & \multicolumn{2}{|c|}{ Un-inoculated } & \multirow{2}{*}{$\begin{array}{c}\text { Removal } \\
\text { Efficiency } \\
(\%)\end{array}$} \\
\hline & & & $\begin{array}{l}\text { Conce- } \\
\text { ntration }\end{array}$ & RT & $\begin{array}{l}\text { Conce- } \\
\text { ntration }\end{array}$ & $\mathrm{RT}$ & \\
\hline Naphthalene & $\mathrm{C}_{10} \mathrm{H}_{8}$ & 128.17 & 28.09 & 10.06 & 0.80 & 10.16 & 97.15 \\
\hline Acenaphthalene & $\mathrm{C}_{12} \mathrm{H}_{8}$ & 152.10 & 35.34 & 11.99 & 1.81 & 12.04 & 94.88 \\
\hline $\begin{array}{l}\text { 1-Methyl } \\
\text { Naphthalene }\end{array}$ & $\mathrm{C}_{11} \mathrm{H}_{10}$ & 142.20 & 3.89 & 15.37 & 0.00 & -- & 100.0 \\
\hline $\begin{array}{c}\text { 2-Methyl } \\
\text { Naphthalene }\end{array}$ & $\mathrm{C}_{11} \mathrm{H}_{10}$ & 142.20 & 2.83 & 15.50 & 1.68 & 15.53 & 40.64 \\
\hline Acenaphthene & $\mathrm{C}_{12} \mathrm{H}_{10}$ & 154.21 & 11.15 & 16.09 & 0.51 & 16.00 & 95.43 \\
\hline Fluorene & $\mathrm{C}_{13} \mathrm{H}_{10}$ & 166.22 & 0.28 & 18.71 & 0.23 & 18.78 & 17.86 \\
\hline Pyrene & $\mathrm{C}_{16} \mathrm{H}_{10}$ & 202.25 & 0.74 & 24.80 & 0.00 & -- & 100.0 \\
\hline Benzo(a)pyrene & $\mathrm{C}_{20} \mathrm{H}_{12}$ & 252.30 & 1.30 & 30.84 & 0.74 & 30.90 & 43.08 \\
\hline $\begin{array}{c}\text { Di- } \\
\text { benzo(a)anthracene }\end{array}$ & $\mathrm{C}_{22} \mathrm{H}_{14}$ & 278.30 & 4.87 & 32.21 & 2.21 & 32.28 & 54.62 \\
\hline
\end{tabular}

MF- Molecular formula; MW- Molecular weight; RT- Retention time

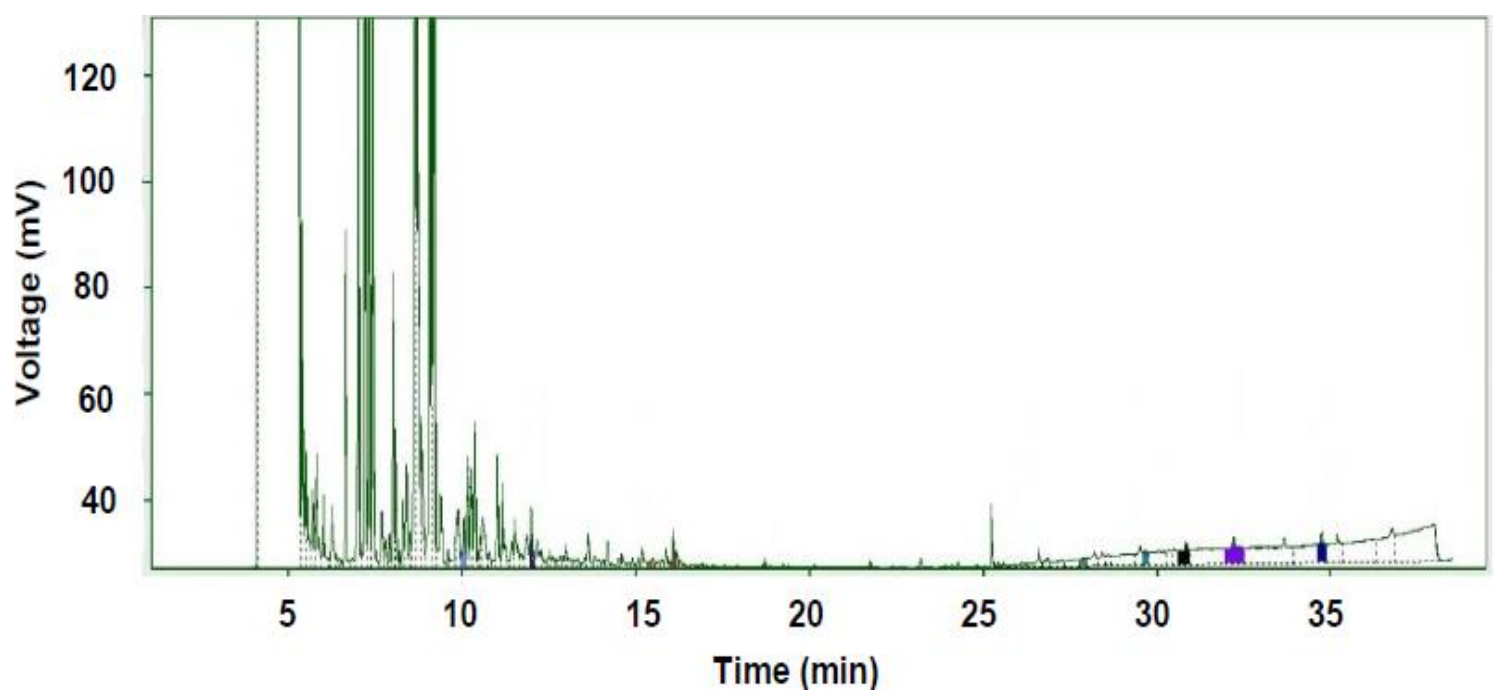

Fig. 2a. GC chromatogram of un-inoculated AR by $T$. asperellum

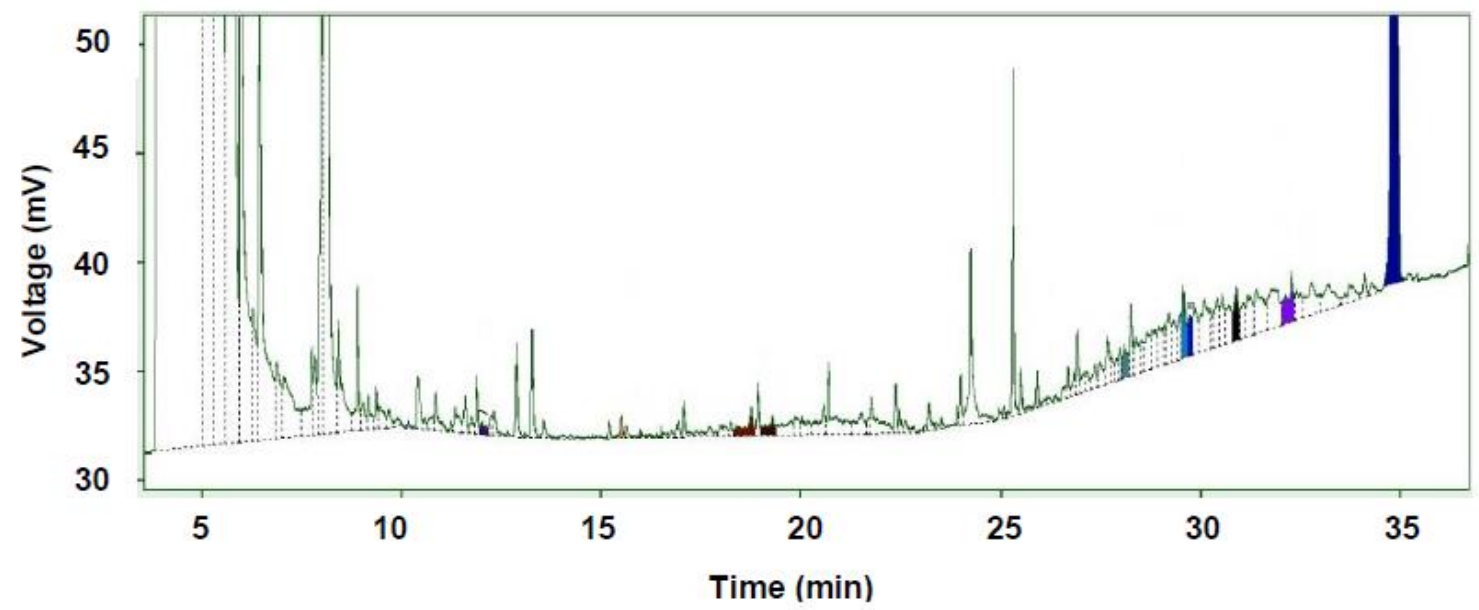

Fig. 2b. GC chromatogram of inoculated AR by T. asperellum 
The results show $100 \%$ removal efficiency for 1-methyl naphthalene and pyrene; 97.2\% for naphthalene; $95.4 \%$ for acenaphthene; $94.9 \%$ for acenaphthalene; $54.6 \%$ for dibenzo(a)anthracene; $43.1 \%$ for benzo(a)pyrene; $40.6 \%$ for 2-methylnaphthalene; and $17.9 \%$ for fluorene. The removal efficiency could be due to the biosorption and bioaccumulation capability of $T$. asperellum and the molecular weight of the organic compounds (Mahmoud et al. 2019).

\section{Microbial Analysis of Soil Irrigated by GW and AR}

Analyzing the microflora of soil irrigated by AR and GW reflected variation in the total number of fungi, bacteria, and actinomycetes (Fig. 3), where the soil irrigated by AR was characterized by the presence of high number of bacteria $\left(32 \times 10^{6} \mathrm{CFU} / / \mathrm{g}\right)$, actinomycetes $\left(18 \times 10^{4} \mathrm{CFU} / / \mathrm{g}\right)$, and fungi $\left(13 \times 10^{4} \mathrm{CFU} / \mathrm{g}\right)$ compared with the soil irrigated by GW. High TSS of AR may positively affect soil microflora by amending the soil with nutrients from different carbon sources. According to a previous report (Zhang et al. 2009; Disciglio et al. 2015), the counts of bacteria, actinomycetes, and fungi in soils irrigated by reclaimed-water were highest compared to tap-water irrigated soil, particularly bacteria. Although Yuan et al. (2003) found that no difference in the quantity of bacteria, actinomycetes, and fungi isolated from irrigated soils by AR or GW. Research is still being conducted on the effect of wastewater and GW on soil microbial population, where Xu et al. (2020) reported that wastewater irrigation changed the bacterial community compared to GW irrigation. Finally, in this section further studies must be carried out to recognize the relationship between microbial species and sewage irrigation soil.

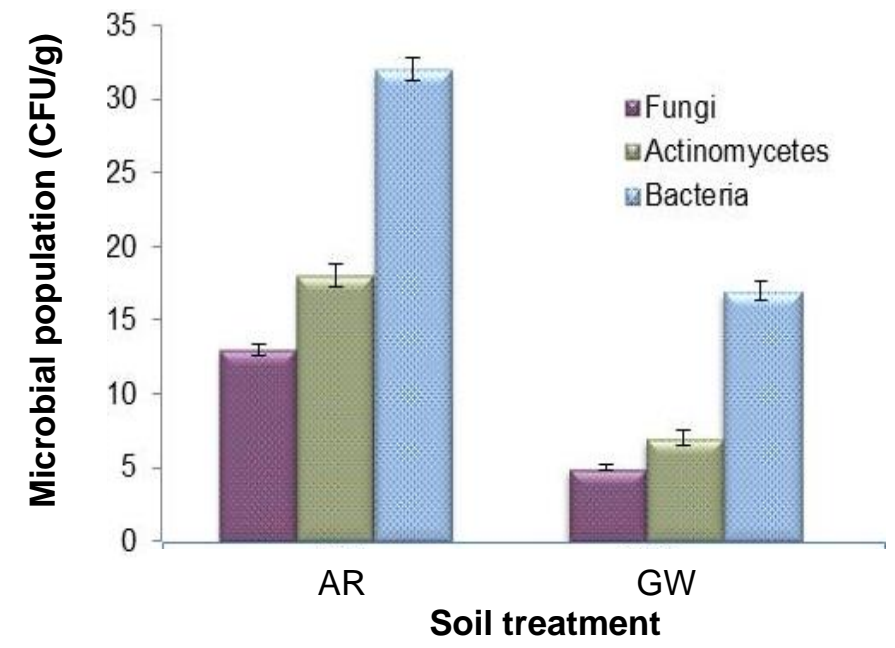

Fig. 3. Microbial population of soil irrigated by $A R$ and GW, fungi (CFU $\left.\times 10^{4}\right)$, actinomycetes $\left(\mathrm{CFU} \times 10^{4}\right)$, and bacteria $\left(\mathrm{CFU} \times 10^{6}\right)$

\section{Oxidative Enzymes of Trifolium alexandrinum Irrigated by GW and AR Inoculated by $T$. asperellum}

Decreased plant growth can be induced by disruption of photosynthesis or mineral nutrient imbalance, which causes a decline in yield (Kalaji et al. 2016). From Fig. 4, it is clear that there was a difference among plant growth, biomass weight, and plant height irrigated by $\mathrm{AR}$ and GW. Inoculated AR by $T$. asperellum induced seed germination with $97.7 \%$ followed by GW inoculated by $T$. asperellum (96\%), followed by un-inoculated AR $(89.3 \%)$ and un-inoculated GW (87\%). 


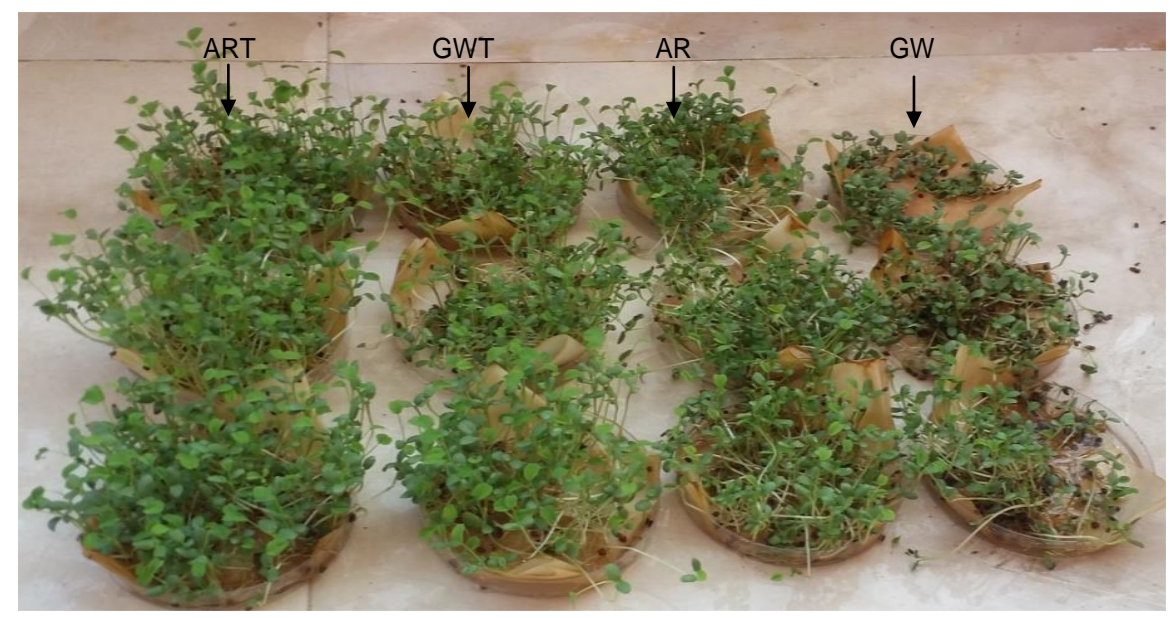

Fig. 4. $T$. alexandrinum irrigated by $\mathrm{GW}$ and $\mathrm{AR}$ inoculated and un-inoculated by $T$. asperellum

Irrigation with GW without $T$. asperellum treatment attained the lowest means of shoot length $(4.5 \mathrm{~cm})$ and biomass $(0.95 \mathrm{~g})$ compared with inoculated AR or GW inoculated by $T$. asperellum (Fig. 5). It is clear from the mentioned results that the AR contains at least the necessary nutrients (organic and inorganic substances) for promotion of plant growth compared to GW water. At the same time, T. asperellum may excrete substances that induce plant growth. There was agreement with Wafaa et al. (2018), who noted that irrigation by AR (50\%) improved biomass, plant height, and dry weight of the maize and barley seedlings compared with the control. Wastewater beneficial effects on plant yields were also documented recently (Neamatallah 2018; Manjunatha et al. 2020). Khadka and Uphoff (2019) reported the vital role of Trichoderma spp. inoculation for plant development, enhanced nutrient uptake, solubilization, sequestration of inorganic nutrients, in addition to the alleviation of biotic and abiotic stresses. The present findings are also in agreement with previous reports (Doni et al. 2014) that revealed the role of $T$. asperellum in promoting and enhancing seedling elongation and physiological response to stress condition. Activity of the antioxidant enzymes CAT, SOD, and APX increased (4.25, 1.53, and $8.25 \mathrm{U} \mathrm{mg}^{-1}$, respectively) in plant irrigated with AR with the addition of $T$. asperellum while it reduced to $3.25,1.12$, and $6.56 \mathrm{U} \mathrm{mg}^{-1}$, respectively, when irrigated by AR without inoculation by T. asperellum (Fig. 5). No remarkable changes were observed in oxidative enzymes activities in plants irrigated with or without T. asperellum (Fig. 5). Indirect effects of $T$. asperellum may act through enhanced production of oxidative enzymes that may enhance the growth in the existence of organic pollutants. The current finding partially agrees with other studies (Joner and Leyval 2001) that reported Glomus mosseae induced oxidative enzymes in white clover and ryegrass grown in soil contaminated by chrysene and dibenz(a,h)anthracene. Generally, any pollutants promote oxidative stress through highest productivity of reactive oxygen species (ROS). Oxidative damage of building molecules for living things may be due to ROS. Antioxidant enzymes play an important role against ROS, particularly SOD. Doni et al. (2015) observed that irrigation by AR enhanced the germination rate, growth, vigour index, and chlorophyll content of rice. Although the plant growth in the current study is not affected negatively by irrigation with $\mathrm{AR}$, the authors expect that with the use of AR for a long period of time, it may affect the quality of the agricultural soil and hence the plants. In addition, it is possible to induce accumulation of some AR components inside the plant. So, the authors suggest that AR can be applied to irrigate woody trees, not vegetables or crops. 

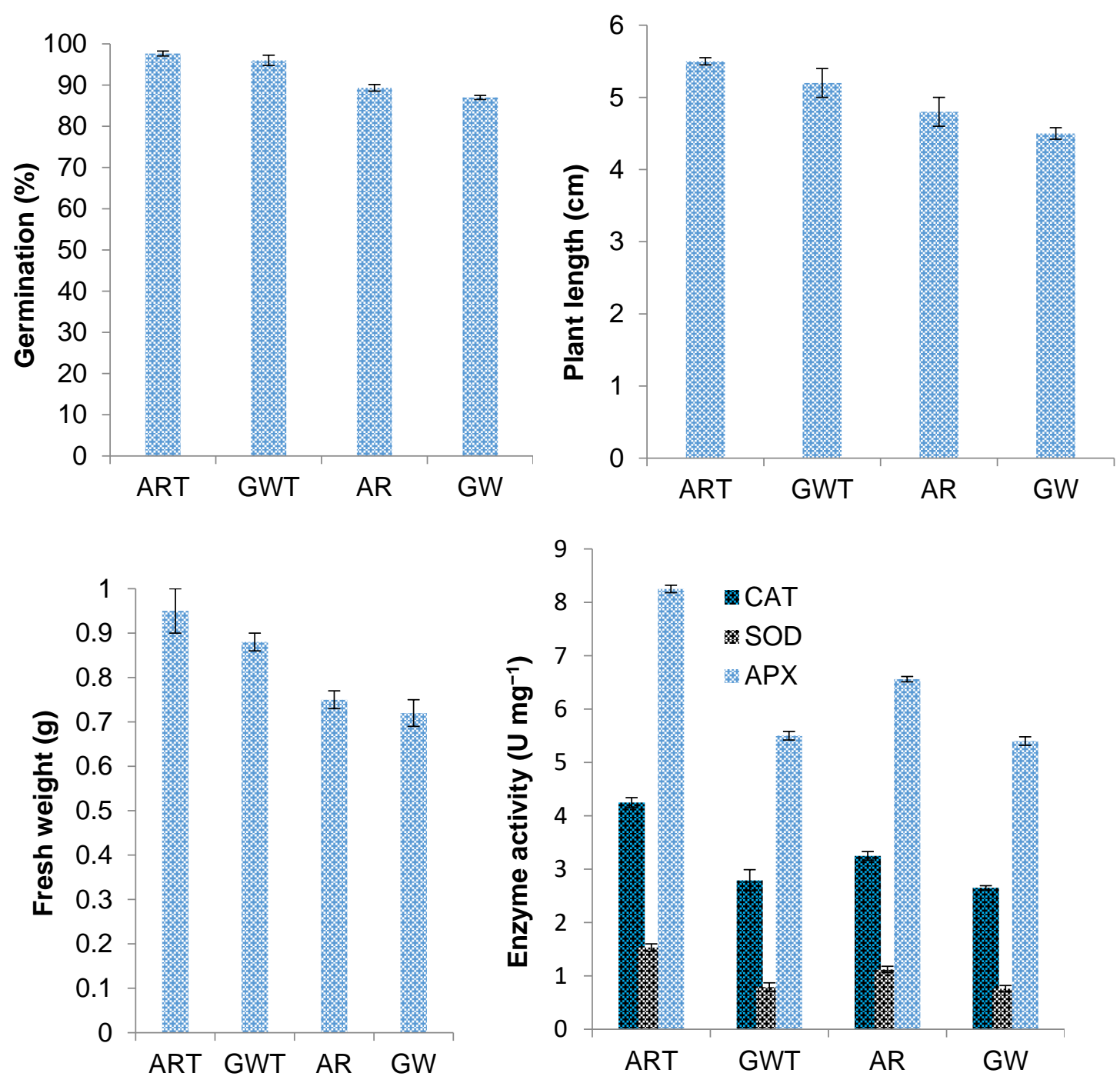

Fig. 5. Growth parameters and oxidative enzymes of $T$. alexandrinum irrigated by GWT and ART inoculated, and by AR and GW un-inoculated by T. asperellum

\section{CONCLUSIONS}

1. The obtained results suggest that $T$. asperellum may minimize the pollutant contents of agricultural runoff (AR) water.

2. T. asperellum enhanced the growth of plants irrigated by AR. Soil irrigated by AR was characterized by the presence of a high content of microorganisms.

3. Irrigation by $\mathrm{AR}$ inoculated by $T$. asperellum increased activities of the antioxidant enzymes CAT, SOD, and APX with $23.53 \%, 26.8 \%$, and $20.5 \%$, respectively, in $T$. alexandrinum compared with the irrigation by un-inoculated $\mathrm{AR}$. 


\section{Conflicts of Interest}

The authors declare that there are no conflicts of interest.

\section{REFERENCES CITED}

Abdel-Ghany, T. M., Ganash, M., Bakri, M. M., and Al-Rajhi, A. M. H. (2018). "Molecular characterization of Trichoderma asperellum and lignocellulolytic activity on barley straw treated with silver nanoparticles," BioResources 13(1), 1729-1744. DOI: 10.15376/biores.13.1.1729-1744

Abdel-Razek, A. S., Abdel-Ghany, T. M., Mahmoud, S. A., El-Sheikh, H. H., and Mahmoud M. S. (2009a). "The use of free and immobilized Cunninghamella elegans for removing cobalt ions from aqueous waste solutions," World Journal Microbiology and Biotechnology 25, 2137-2145. DOI:10.1007/s11274-009-0118-z

Abdel-Razek, A. S., Abdel-Ghany, T. M., Mahmoud, S. A., El-Sheikh H. H., and Mahmoud, M. S. (2009b). "Treatment of liquid hazardous wastes by using the fungus Cunninghamella elegans," Journal of Radiation Research and Applied Sciences 2(5), 890-902.

Aiello, R., Cirelli, L.G., and Consoli, S. (2007). "Effect of reclaimed wastewater irrigation on soil and tomato fruits: A case study in Sicily (Italy)," Agricultural Water Management 93(1-2), 65-72. DOI: 10.1016/j.agwat.2007.06.008

Al-Tabbal, J., Al-Zboon, K., Al-Zouby, J., Al-Smadi, B., and Ammary, B. (2016). "Effect of zeolux use on sage (Salvia officinalis) plant irrigated by fresh and RO reject waters," GlobalNEST International Journal 18(2), 416-425. DOI: 10.30955/gnj.001569

Bedbabis, S., Ferrara, G., Ben Rouina, B., and Boukhris, M. (2010). "Effects of irrigation with treated wastewater on olive tree growth, yield and leaf mineral elements at short term," Scientia Horticulturae 126(3), 345-350. DOI: 10.1016/j.scienta.2010.07.020

Behnami, A., Benis, K. Z., Shakerkhatibi, M., Derafshi, S., Saber, A. B., Akbarif, N. A. R., and Yousefi, R. (2018). "Comparative study on fungal communities of full scale municipal and industrial wastewater treatment plants," Desalination and Water Treatment, 131, 123-131. DOI: 10.5004/dwt.2018.22948

Disciglio, G., Gatta, G., Libutti, A., Gagliardi, A., Carlucci, A., Lops, F., Cibelli, F., and Tarantino, A. (2015). "Effects of irrigation with treated agro-industrial wastewater on soil chemical characteristics and fungal populations during processing tomato crop cycle," Journal of Soil Science and Plant Nutrition 15(3), 765-780. DOI: 10.4067/S0718-95162015005000052

Doni, F., Isahak, A., Zain, C. R. C. M., and Yusoff, W. M. W. (2014). "Physiological and growth response of rice plants (Oryza sativa L.) to Trichoderma spp. inoculants," $A M B$ Express 4, Article Number 1. DOI: 10.1186/2191-0855-4-1

Fakhrul-Razi, A., Alam, M. Z., Idris, A., Abd-Aziz, S., and Molla, A.H. (2002). "Filamentous fungi in Indah Water Konsortium (IWK) sewage treatment plant for biological treatment of domestic wastewater sludge," Journal of Environmental Science and Health - Part A Toxic/Hazardous Substances and Environmental Engineering 37(3), 309-320. DOI: 10.1081/ese-120002830

Giannopolitis, C. N., and Ries, S. K. (1977). "Superoxide dismutases: I. Occurrence in higher plants," Plant Physiology 59(2), 309-314. DOI: 10.1104/pp.59.2.309

Gomez, C., Escudero, R., Morales, M. M., Figueroa, F. L., Fernandez-Sevilla, J. M., and 
Acien, F. G. (2013). "Use of secondary-treated wastewater for the production of Muriellopsis sp.," Applied Microbiology and Biotechnology 97(5), 2239-2249. DOI: 10.1007/s00253-012-4634-7

Guest, R. K., and Smith, D. W. (2007). "Isolation and screening of fungi to determine potential for ammonia nitrogen treatment in wastewater," Journal of Environmental Engineering and Science 6(2), 209-217 DOI: 10.1139/s06-050

Lado, M., and Ben-Hur, M. (2010). "Effects of irrigation with different effluents on saturated hydraulic conductivity of arid and semiarid soils," Soil Science Society of America Journal 74(1), 23-32. DOI: 10.2136/sssaj2009.0114

Manici, L. M., Caputo, F., and Bambini, V. (2004). "Effect of green manure on Pythium spp. population and microbial communities in intensive cropping systems," Plant Soil 263(1-2), 133-142. DOI: 10.4067/S0718-95162015005000052

Manjunatha, M. V., Prasanna, K. B. H., Sunil, A. S., and Manjunatha, H. (2020). "Response of different sources of irrigation with graded levels of fertilizer on yield, water productivity and economics of French bean," Journal of Pharmacognosy and Phytochemistry SP6, 387-391.

Manna, M. C., Sahu, A., De, N., Thakur, J. K., Mandal, A., Bhattacharjya, S., Ghosh, A., Rahman, M. M., Naidu, R., Singh, U. B., Dakhli, R., Sharma, M. P., and Misra, S. (2020). "Novel bio-filtration method for the removal of heavy metals from municipal solid waste," Environ. Technol. Innov. 17, 100619. DOI: 10.1016/j.eti.2020.100619

Mohsenzadeh, F., and Shahrokhi, F. (2014). "Biological removing of cadmium from contaminated media by fungal biomass of Trichoderma species," Journal of Environmental Health Science and Engineering 12, Article Number 102. DOI: $10.1186 / 2052-336 \mathrm{X}-12-102$

Nakano, Y., and Asada, K. (1981). "Hydrogen peroxide is scavenged by ascorbatespecific peroxidase in spinach chloroplasts," Plant and Cell Physiology 22, 867-880. DOI: 10.1093/oxfordjournals.pcp. a076232

Narendran, R., Kathiresan, K., Sathishkumar, R. S., Kayalvizhi, K., and Sundaramanickam, A. (2019). "Bioremoval of toxic substances in synthetic wastewater using Trichoderma pubescens (NPK2), isolated from mangrove soil," Biocatalysis and Agricultural Biotechnology 19, Article ID 101100. DOI: 10.1016/j.bcab.2019.101100

Neamatallah, A. A. (2018). "The effect of the use of sewage water from the treatment plant in Makkah Al Mukarramah on the dry forage yield and microbiological characteristics of Sudan grass (Sorghum Sudanensis L.)," International Journal of Agriculture Innovations and Research 7(3), 298-302.

Reyes-Solis, I. E., Garcia-Calderon, N. E., and Servin-Ruiz, D. E. (2003). "Wastewaterirrigation effect in physical and chemical soil properties of Mezquital Valley, Hidalgo state, Mexico," Geochimica Et Cosmochimica Acta 67(18), A396-A396.

Rice, E. W., Baird, R. B., and Eaton, A. D. (2017). Standard Methods for the Examination of Water and Wastewater, $23^{\text {rd }}$ Edition, American Public Health Association, American Water Works Association, Water Environment Federation, Washington D.C., USA.

Singh, P. K., Deshbhratar, P. B., and Ramteke, D. S. (2012). "Effects of sewage wastewater irrigation on soil properties, crop yield and environment," Agricultural Water Management 103, 100-104. DOI: 10.1016/j.agwat.2011.10.022

Su, Z-H., Mahmoud, M. S., Fan, S-J., Yu, Z., and Peng, F. (2019). "Combustion properties of mixed black liquor solids from linter and reed pulping," BioResources 
14(4), 8278-8288. DOI: 10.15376/biores.14.4.8278-8288

Su, Z.-H., Fan, S.-J., Zhang, Y., Tian C., Gong, C., Ni, J.-P., Yang B., Peng, F., Korkko, M., and Mahmoud, M. S. (2020). "Industrial scale-up of fiber recovery technology from mixed office waste fine screen reject," BioResources 15(3), 6420-6430, DOI: 10.15376/biores.15.3.6420-6430

Wafaa, S. A. A., Luma, A. S. A., and Hussein, M. K. (2018). "Effect of sewage water irrigation on growth performance, biomass and nutrient accumulation in maize and barley," International Journal of Agricultural and Statistics Sciences 14(2), 519-524. DOI: 10.13140/RG.2.2.28409.31847

Wang, M., Zhang, D., Dong, J., and Tan, S. K. (2018). “Application of constructed wetlands for treating agricultural runoff and agro-industrial wastewater: A review. Hydrobiologia 805, 1-31. DOI: 10.1007/s10750-017-3315-z

Xu, X., Liu, S., Zhu, X., and Guo, X. (2020). "Comparative study on soil microbial diversity and structure under wastewater and groundwater irrigation conditions," Current Microbiology 77, 3909-3918. DOI: 10.1007/s00284-020-02219-5

Xue, Y. D., Yang, P. L., Luo, Y. P., Li, Y. K., Ren, S. M., and Su, Y. P. (2012). "Characteristics and driven factors of nitrous oxide and carbon dioxide emissions in soil irrigated with treated wastewater," Journal of Integrative Agriculture 11(8), 1354-1364. DOI: 10.1016/S2095-3119(12)60134-8

Ye, Y., Gan, J., and Hu, B. (2015). "Screening of phosphorus-accumulating fungi and their potential for phosphorus removal from waste streams," Applied Biochemistry and Biotechnology 177(5), 1127-1136. DOI: 10.1007/s12010-015-1801-1

Yuan, Y. W., Zhang, W., and Ma, W. (2003). "Influence of sewage irrigation on quantity of various microorganism groups in soil," Water Saving Irrigation 6, 15-17.

Zavadil, J. (2009). "The effect of municipal wastewater irrigation on the yield and quality of vegetables and crops," Soil and Water Research 4(3), 91-103. DOI: 10.17221/40/2008-SWR

Zhang, Z. Y., Jin, B., Bai, Z. H., and Wang, X. Y. (2008). "Production of fungal biomass protein using microfungi from winery wastewater treatment," Bioresource Technology 99(9), 3871-3876. DOI: 10.1016/j.biortech.2006.10.047

Zhang, D., Yin, C., Abbas, N., Mao, Z., and Zhang, Y. (2020). "Multiple heavy metal tolerance and removal by an earthworm gut fungus Trichoderma brevicompactum QYCD-6," Scientific Reports 10, article no. 6940. DOI:10.1038/s41598-020-63813-y

Article submitted: January 23, 2021; Peer review completed: March 6, 2021; Revised version received: March 8, 2021; Accepted: March 9, 2021; Published: March 16, 2021. DOI: 10.15376/biores.16.2.3272-3284 